\title{
Integrating integrated water management
}

Mark Everard PhD

Associate Professor of Ecosystem Services, Faculty of Environment and

Technology, University of the West of England (UWE), Bristol, UK

The water cycle is a contiguous system interconnected with human activities. Management has tended to be fragmented across anthropocentrically defined disciplines, potentially generating unintended negative consequences. The ecosystem approach and the ecosystem services framework emphasise interlinked, albeit often overlooked, benefits that the natural environment provides for people. This enables recognition and avoidance of potential 'negative externalities', identification of solutions optimising benefits across multiple services, and participation of wider constituencies of stakeholders. Systemic, outcome-based approaches are inherently economically efficient, yielding greater cumulative benefits for lower transaction costs by working with natural processes. The ecosystem approach establishes geographical and socio-economic contexts for management ecosystem service outcomes, providing a broader context in which to nest established water resource management methods. The ecosystem approach can also be applied at different scales and to diverse societal activities, internalising into them the value of natural processes. It is amenable to integration into catchment-scale considerations, yet does not present these activities as subsidiary to river basin planning. The addition of ecosystem services for options appraisal in preexisting decision-support tools adapts them to better address multi-benefit goals. Shifts are required in the policy and economic environment, but engineers have an important role in promoting, applying and innovating multibenefit solutions.

\section{Introduction}

The water cycle is a contiguous system, cycling renewably through the atmosphere, landscapes and water bodies, and carrying with it solutes, energy, suspended matter and biota. Living organisms use and modify these flows, forming elaborate and resilient ecosystems comprising both living and non-living elements that are integral to the efficiency and sustainability of the overall cycle.

Humanity is one of these living organisms, albeit one with a disproportionate impact on the Earth's biosphere, including the water cycle. It is for this reason that many observers define this as the Anthropocene epoch - the age when human impacts predominate over the self-regulatory capacities of the Earth system - bringing to an end a Holocene epoch defined by wholly natural processes (Crutzen and Stoermer, 2000). The need to moderate and modify human pressures has resulted in a range of approaches to integrated management of the water cycle.

Prominent examples include catchment management planning (CMP, also known as river basin management), and represent a first step towards integration of management disciplines within river basins. A wider systemic approach is embraced by the concept of integrated catchment management which expands in vision to a strategic approach to land and water management designed to help multiple stakeholders make informed decisions and take coordinated action to manage a complex environmental system (Mitchell and Hollick, 1993). Its successor, integrated water resource management (IWRM), recognises the interdependence of water quality, water resources and biodiversity with catchment land use and other economic activities (Calder, 1999). The IWRM approach is defined by the four Dublin Principles (Global Water Partnership, 2000), which include: recognition of fresh water as a finite and vulnerable resource requiring a holistic approach linking social and economic development with protection of natural ecosystems; the necessity of a participatory approach involving users, planners and policy makers at all levels; that women play a central part in the provision, management and safeguarding of water; and that water has an economic value in all its competing uses and should be recognised as an economic good. Adaptive water resources management (AWRM) represents a further evolution to reflect that outcomes of management can be unpredictable, and there is therefore a need to include reflexive feedback loops (Pahl-Wostl and Sendzimir, 2005), although AWRM is in essence part of a wider IWRM 'family' of approaches (Allan, 2003; Global Water Partnership, 2000; Mitchell, 2004; Radif, 1999). A progressive generation of regulations such as the EU Water Framework Directive (WFD) (European Commission, 2000) focus on integrated outcomes for the chemical and biological status of water bodies, acknowledging and requiring management of multiple driving pressures through river basin management (RBM) processes. This canon of management approaches therefore represents a progressive expansion of scope to account for more dimensions of inherently connected socioecological catchment systems. 


\section{Offprint provided courtesy of www.icevirtuallibrary.com Author copy for personal use, not for distribution}

There is generally a significant shortfall between practical implementation and the visionary aspirations of these integrated approaches to water management, with often fragmented disciplinary application and the continued dominance of interest-based uses of catchment systems (Born and Sonzogni, 1995). This is problematic as it perpetuates locally interest-led exploitation of landscapes, regardless of ramifications for the users of other water-mediated benefits. An extreme example of this 'riparian principle' in practice is within much South African legislation of the apartheid era including, for example, the Irrigation and Conservation of Waters Act 1912 (Republic of South Africa, 1912), which states that 'He can do whatsoever he pleases with it and neither the owners of lower-lying land nor even the public can claim to be entitled to make any use at all of that water'.

In the less extreme situations that commonly occur in the modern era across the world, the very division of management focus into discrete anthropocentrically defined disciplines has frequently resulted in narrow solutions leading to unintended consequences across management disciplines. One of many examples is the exacerbation of impacts on the climate system from increased energy use, chemical inputs with associated equity issues along supply chains, increasing waste generation and haulage-related disturbance, all stemming as collateral impacts from more intensive treatment of wastewater. This problem is particularly acute for benefits provided for the environment that have been assumed for too long to be 'for free', such as climate and air quality regulation or the regeneration of fish stocks in international waters, the degradation of which has been a classic illustration of the metaphor of the 'tragedy of the commons' (Hardin, 1968), wherein commonly held resources tend, without robust communal stewardship, to become degraded through exploitation by private interests, with the unaccounted costs borne by all who would otherwise benefit from the resource.

Progress has certainly been made implementing some more integrated approaches such as IWRM, though application has often been undertaken on a technocentric, expert-driven basis, often supported by some form of modelling. This tends to limit the scope for taking account of the diversity of perspectives and value systems of all sectors of society who influence and are in turn affected by the water cycle (Saravanan et al., 2009). Implementation of bold visionary approaches has often also been blinkered by legacy world views and assumptions. A classic example of this is the WFD which, although inherently more systemic in construction than prior management regimen, was implemented in the UK through its first management cycle (as reviewed subsequently in this paper) as a process for meeting quality standards rather than addressing directly the Directive's intent to secure the multiple benefits of a more resilient water cycle (Everard, 2011).

Transitions in the philosophical approach to the management of flooding across much of the developed world, particularly since the dawn of this millennium, has resulted in shifts in policy and practice from traditional 'hard engineering', such as installation of flood walls around land or infrastructure to be 'defended', towards a softer approach that recognises the need to 'work with nature' by exploiting natural processes such as allowing flood water to be detained on flood plains and in wetlands (Defra, 2005; Pitt, 2007) as well as the setting back of defences with coincidental co-benefits for water quality, biodiversity, the visual landscape and carbon sequestration (Meijerinka and Dicke, 2008). To optimise the beneficial outcomes of management as well as to prevent future unintended consequences from restrictive disciplinary framing of solutions, there is a pressing need to drive further innovation in thinking and practice, particularly as it relates to crucial natural resources such as the water cycle.

\section{The ecosystem approach as an integrating framework}

The ecosystem approach, defined by the Convention on Biological Diversity (the CBD: www.cbd.int) in 1995 as '...a strategy for the integrated management of land, water and living resources that promotes conservation and sustainable use in an equitable way', recognises humans and their economic and other activities as central and interdependent components of ecosystems. The CBD identifies 12 'complementary and interlinked' principles for the application of the ecosystem approach, summarised in the first column of Table 1.

Central to the ecosystem approach is the concept of ecosystem services. Ecosystem services are defined by the Millennium Ecosystem Assessment (2005) as '...the benefits people obtain from ecosystems'. A diversity of ecosystem service classification schemes has been developed since the late 1980s, generally addressing discrete habitat types within specific bioregions of the world, such as tropical wetlands, coral reefs, forests or rangelands. The Millennium Ecosystem Assessment (2005) drew upon this variety of pre-existing categorisations to create a harmonised international classification scheme of ecosystem services, enabling comparison between habitat types and across biogeographical regions. The Millennium Ecosystem Assessment classification of ecosystem services reflects a generically applicable assessment of the breadth of benefits that ecosystems provide to people, taking account of cultural diversity and associated values (both economic and non-economic). The Millennium Ecosystem Assessment classification of ecosystem services recognises four principal categories.

- Provisioning services, comprising tangible, extractable and often tradable assets derived from ecosystems including, for example, food, fibre, natural medicines, fresh water and energy.

- Regulatory services, referring to natural processes that regulate factors such as air quality, climate and microclimate, water purification, storm and natural hazard protection, disease and pest, etc.

- Cultural services that provide less tangible benefits such as aesthetics and regional character, educational, tourism and recreational opportunities, artistic inspiration, etc. 


\section{Offprint provided courtesy of www.icevirtuallibrary.com Author copy for personal use, not for distribution}

- Supporting services which comprise a range of processes maintaining ecosystem integrity, functioning and capacity to supply other services, such as soil formation, habitats for wildlife, nutrient cycling and primary production.

Importantly, this harmonised international framework of ecosystem services reflects systemic interactions between elements of the environment, the services that it provides, and the ways that service exploitation by a subset of people can affect the benefits enjoyed by others. For example, modern intensive food production systems (farming of land, capture fishing, aquaculture, etc.) have substantially boosted production of a narrow subset of provisioning services (particularly food and fibre) but at substantial, if unintended and largely underappreciated, cost to the capacity of landscapes and waterscapes to regulate climate, hydrology, soil erosion and water quality, to maintain fisheries and traditional and valued landscapes, and to sustain supporting services such as habitat for wildlife and essential processes including soil formation and nutrient cycling. An analysis reported in the Millennium Ecosystem Assessment (2005) concluded that the 'external cost of agriculture in the UK in 1996' (comprising damage to water, soil and biodiversity) amounted to some US $\$ 2.6$ billion, or $9 \%$ of yearly gross farm receipts. The net costs of a narrow focus on any one service may therefore be substantial if wider negative consequences for other services and constituencies of society, including future generations, are overlooked.

As an integrated framework, ecosystem services engage with sustainable development issues as outputs from ecosystems, recognising the inherent interdependence of the benefits that people derive from natural systems. These service outputs are relevant to all human interests, from basic biophysical health and wellbeing, security of economic resources, broader 'quality of life' factors and the overall resilience of the socio-ecological system. As observed previously, the canon of water and catchment management approaches represents an evolution in scope to take account of more connected facets affecting and affected by the water cycle. The ecosystem approach differs in that the focus is not specifically on water but on the interdependence of all domains of societal activities on ecosystem structure, functioning and benefits. Table 1 articulates the 'fit' of catchment management approaches with the twelve principles defining the ecosystem approach.

The analysis in Table 1 reveals the progressive evolution of water and catchment planning initiatives, as identified previously, but also how the ecosystem approach may represent a more integrated framework within which to consider the interactions of the management of land and water and other interdependent societal activities and priorities.

One of the qualitative differences of the ecosystem approach is that it is not bounded by watersheds, although it may be applied at that scale. Another highly significant qualitative difference is that the ecosystem approach can be applied as a broader contextual strategy to a wide range of societal activities (including for example land use practices, industrial processes and supply chains, development proposals, and tests of likely outcomes for policy proposals) rather than attempting to include these activities within geographically bound plans. It thereby offers greater freedoms for those with interests in activities that impinge upon, exploit or are affected by management of the water cycle by emphasising interactions with ecosystems and their other co-beneficiaries, providing a basis for innovation of beneficial outcomes (be that for a private company developing a product, a municipality designing a public space or any of a range of societal activities) rather than conveying the sense of having to 'fit in' with a catchment plan. The ecosystem processes, outcomes and interactions of the focal activity and of the catchment can be overlain, but neither is subsidiary to the other. This is, arguably, a more effective means to address the diversity of '. . forms of relevant information, including scientific and indigenous and local knowledge, innovations and practices' (highlighted by principle 11 of the ecosystem approach) than by seeking to deduce and integrate them in a centralised river basin plan. It is certainly a more flexible means to embed the value of ecosystems and their processes into the mainstream of society's diverse activities and deliberations.

The ecosystem approach thereby acknowledges the complexity of interactions between the needs, activities and sovereignty of different sectors of society and of the natural systems that ultimately provide the resources underpinning them. By taking as its reference interlinked outputs, the ecosystem services framework overcomes the traditional 'silo' perspective of management of the water cycle and wider environment on a discrete disciplineby-discipline basis. The twelve principles of the ecosystem approach set an approach to addressing ecosystem service outcomes within broader geographical and socio-economic systemic contexts, supporting a truly integrated approach to evaluating the consequences of decisions and actions. Importantly, the ecosystem approach also provides a framework against which to innovate measures and technical solutions that maximise public value by optimising the protection or regeneration of all categories of ecosystem services, rather than a narrow favoured subset of them.

Reviewing a range of ecosystem service case studies assessing the outcomes of water-related management interventions, Everard (2012) identified seven principal lessons.

1. System-level assessment may lead to different outcomes compared to traditional, discipline-focused assessment.

2. Ecosystem restoration maximises value across all ecosystem services.

3. Stakeholder participation enhances evaluation and decisionmaking processes.

4. Ecosystem services help communicate key issues and engage people.

5. Local schemes designed in the context of catchment functioning can contribute to sustainability. 


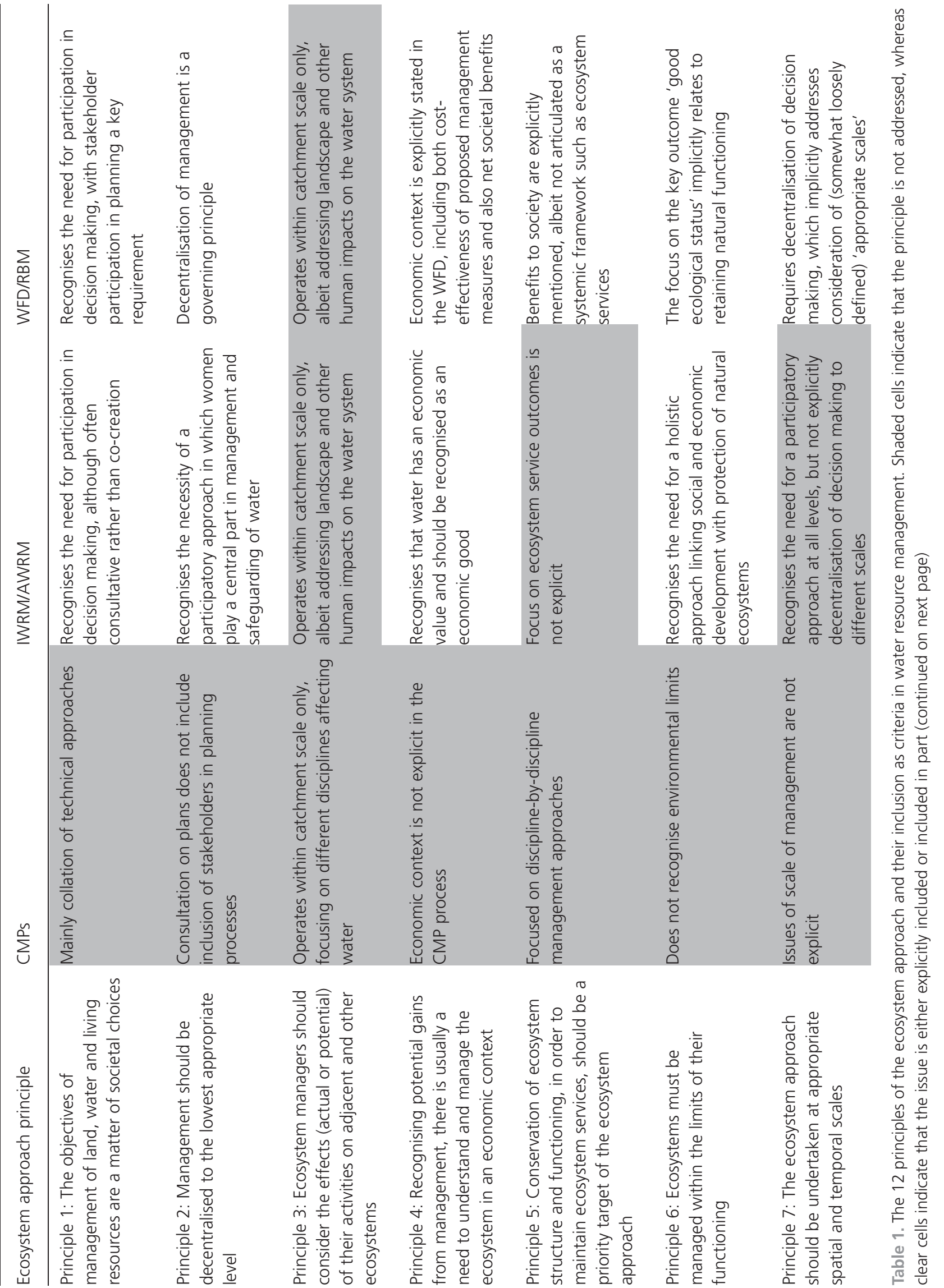




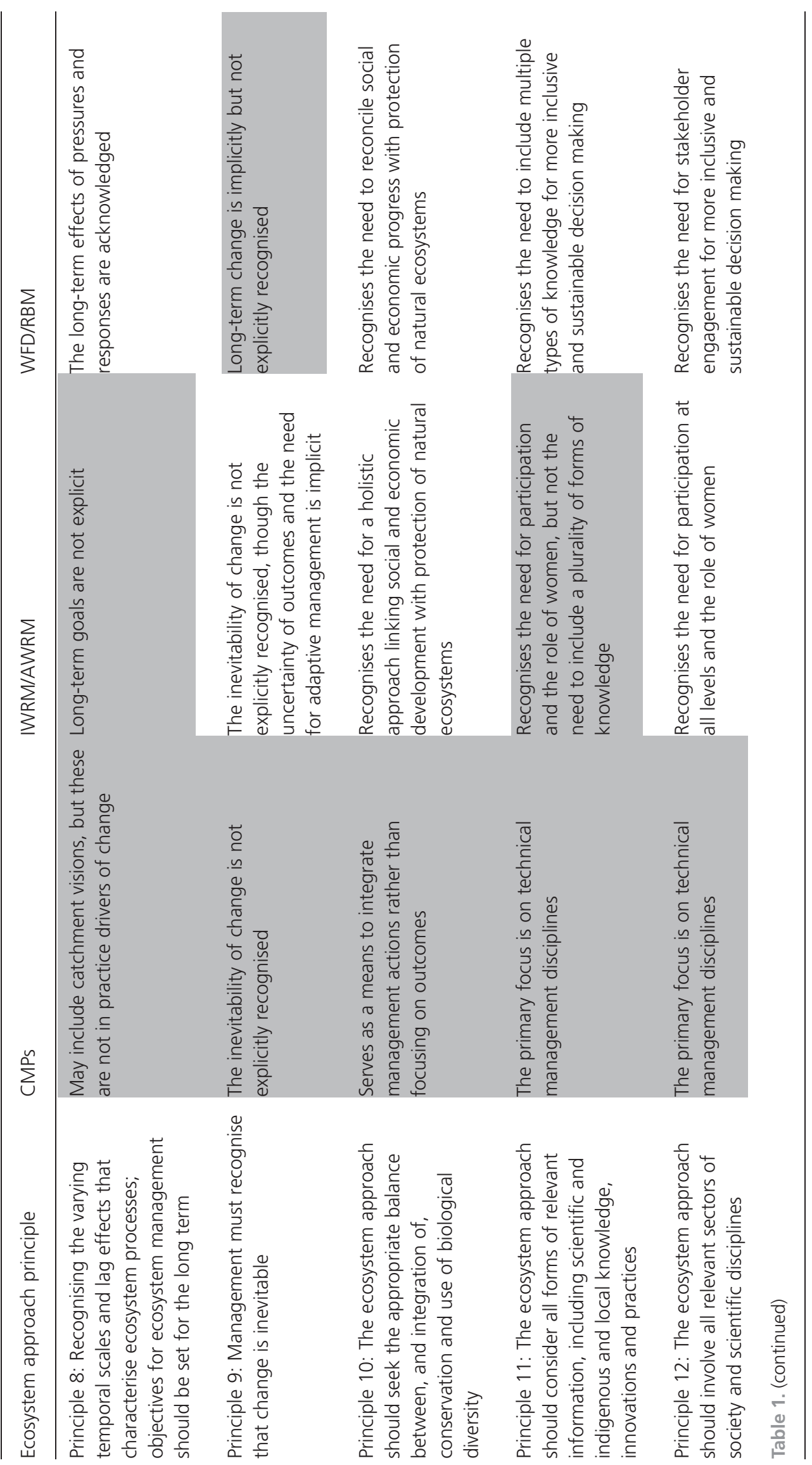




\section{Offprint provided courtesy of www.icevirtuallibrary.com Author copy for personal use, not for distribution}

6. Markets have a key role to play in realising the benefits of ecosystem services.

7. Systemic perspectives should be built into management tools.

This cascade of lessons reflects the importance of setting consideration in a systemic context that addresses impacts across contiguous socio-ecological systems, engages with the diversity of interdependent stakeholders and economic implications, and concludes with an emphasis of translation of systemic intent into practical tools.

While acknowledging a need for some new tools, it is important to recognise the value of existing tools and techniques once reframed in a systemic context. Existing approaches such as CMPs, IWRM/AWRM and WFD remain important to bring together water management disciplines. Progressive legislation, such as the WFD, also has an influential role to play, although Everard (2011) raised the question "Why does "good ecological status" matter?' when questioning interpretation by the UK of the WFD in the first round of implementation (RBM1). The word 'standards' appears in only two of the 53 paragraphs of the preamble of the WFD, which sets out the purpose of the Directive itself, both times in connection with control of pollutants (European Commission, 2000). However, the first round of implementation of the WFD in the UK (RBM1) centred on compliance with more than 50 sets of standards for various chemical and biological parameters. The intent of the WFD is elaborated in its preamble as 'Water is not a commercial product like any other but, rather, a heritage which must be protected, defended and treated as such' (paragraph 1) presenting '. . basic principles of sustainable water policy' (paragraph 6 ) in '...pursuit of the objectives of preserving, protecting and improving the quality of the environment, in prudent and rational utilisation of natural resources, and to be based on the precautionary principle and on the principles that preventive action should be taken, environmental damage should, as a priority, be rectified at source and that the polluter should pay' (paragraph 11) which, together with the other 42 paragraphs, requires a more systemic approach addressing multiple benefits to society. The fit of this systemic intent with the ecosystem services framework and the ecosystem approach is clear.

Many pre-existing environmental management and development tools, including environmental impact assessment, strategic environmental assessment and other spatial planning tools, remain valuable for determining land use options. These various optionsappraisal and decision-support tools could be readily broadened by government-level guidance requiring their interpretation against the broader systemic context of the ecosystem services framework. This would not require any new primary legislation yet would promote more inclusive and better-integrated outcomes using established techniques. This shift in interpretation is implicit in the UK Government white paper The Natural Choice (HM Government, 2011), but may require further explicit guidance to give decision makers and solutions engineers confidence in practical implementation. Were this explicit guidance to emerge, it would significantly raise awareness of opportunities to avoid negative trade-offs and, instead, to innovate win-win solutions to management challenges that deliver benefits across more of the ecosystem services framework, thereby maximising societal value. An outcome-based focus addressing wider implications for all ecosystem services as a connected set, including outcomes for their equally broad diverse collection of beneficiaries, offers the prospect of increasing the level of multidisciplinary benefits arising from policy and management interventions. Although win-win outcomes may not always be possible in practice, adding a systemic basis to decision support that addresses interdependences within and between human interests and the environment provides transparency and a more inclusive basis recognising overall outcomes for future human wellbeing and public value.

\section{Systemic solutions}

A range of 'systemic solutions', making use of natural processes with low inputs and intentionally optimising outcomes across a broader suite of ecosystem services, is breaking through into the mainstream of environmental management practice (Everard and McInnes, 2013).

Sustainable drainage systems (SuDS), more commonly known in the USA as 'source control' techniques, emulate natural drainage and infiltration processes through a diversity of engineered solutions (including, for example, detention ponds and basins, vegetated swales, rain gardens and constructed reed beds), mainly adapted to urban spaces but also applicable to the rural situations. Whereas SuDS techniques can be applied for narrowly prescribed drainage purposes, they can also be developed adaptively to deliver a number of linked benefits, typically including water quality regulation, amenity provision and habitat for wildlife (Woods-Ballard et al., 2007). Extending these principles, green infrastructure (GI) is a more generic and flexible approach addressing the protection, restoration or emulation of natural habitats, and may address the same set of benefits as SuDS in addition to creating urban green spaces, natural cooling, lowcarbon travelling routes (walking and cycle paths, etc.) and 'scrubbing' fine particulates and other air pollutants (Center for Clean Air Policy, 2011; Natural England, 2009). These approaches may be linked with 'green building' techniques such as 'green roofs' and natural shading that exploit natural processes in the urban environment (Grant, 2012). This extension of consideration to a broader basket of ecosystem services reflects the importance of natural processes for the physical, mental and social wellbeing of people (World Health Organization, 2005). The beneficial impacts of access to natural or semi-natural environments is recognised in market terms by the significant economic uplift in value of domestic and industrial buildings in proximity to 'green' and 'blue' spaces (Dunse et al., 2007; Trust for Public Land, 2008; Urban Parks Forum, 2002). A study of an inner city parkland regeneration, including restoration of a small river in east London, UK, quantified a wide range of ecosystem 


\section{Offprint provided courtesy of www.icevirtuallibrary.com Author copy for personal use, not for distribution}

service benefits to local people, including health, wellbeing, economic and wildlife improvements, concluding that benefits that could be valued in economic terms (though many more benefits considered significant eluded confident valuation) were worth up to seven times the cost of the whole regeneration scheme (Everard et al., 2011).

A more radically cross-disciplinary approach to harnessing the multiple values of natural processes is seen in integrated constructed wetlands (ICWs), widely applied across County Waterford and elsewhere in the Republic of Ireland, which deliberately seek to optimise the production of a broad range of ecosystem services provided by cascades of shallow, aerobic wetland cells (Scholz et al., 2007). Examples of effective and long-running ICWs in the Anne Valley of County Waterford address total drainage and wastewater treatment from industrial units, a village, some 16 intensive farmed livestock units, as well as individual houses and interception of field run-off (Everard et al., 2012). This network of ICWs not only efficiently treats pollution and cycles nutrients in the Anne Valley, but also buffers hydrology, and has thereby contributed significantly to the ecological recovery of the river system from former land drainage activities undertaken in the 1980s restoring locally valued natural landscapes, amenity and wildlife.

A parallel extension of objectives is seen in the evolution of river restoration techniques, broadening from a narrow 'habitats and species' focus in the 1980s through to today, to addressing natural flood management, provision of attractive and biodiverse landscapes, spawning and nursery areas for self-sustaining fish stocks, carbon sequestration and nutrient cycling, among a range of other services (Everard and Moggridge, 2012).

Water industry investment in the UK is also undergoing a marked transition towards a more systemic approach. The overwhelming bulk of investment in the quality of supply of piped water from 1990 to 2010 was on advanced, generally energy-, chemical- and waste-intensive treatment processes to purify raw water at the point of abstraction. However, the focus is now shifting towards catchment-scale initiatives such as SCaMP (www.unitedutilities. com/scamp.aspx) in the north-west of England and 'Upstream Thinking' (www.upstreamthinking.org) in the south west. These catchment-based schemes recycle a proportion of investment drawn from customer bills to subsidise agricultural land use within catchments serving surface water abstraction points, reducing the quantity of particulate, soluble and microbial pollutants at source. OFWAT, the economic regulator of the water industry in England and Wales, accepts that 'Upstream Thinking' represents a $65: 1$ benefit-to-cost ratio over a 30 -year period relative to downstream treatment of contaminated water, with additional cobenefits for the ecological quality of rivers and associated fisheries, wildlife and ecotourism values (South West Water, 2012).

This shift in focus from traditional 'hard engineering' solutions is highlighting the value creation potential of exploiting, emulating or working with natural processes. These values may accrue not merely to water services (such as enhanced cleanliness and reliability of flows of water at the point of abstraction, more dilution capacity for effluent, and reduced sewer and urban flooding) but via a range of diverse additional services such as enhanced biodiversity, nutrient cycling, perceived naturalness of landscape promoting ecotourism, and fishery regeneration. These successes, brokered often in partnership between nongovernmental organisations (NGOs) and water service companies, are now being taken up into UK government policy under the catchment-based approach (Defra, 2013).

Some of these multi-service systemic solutions already form part of current management practices, including for example recognition of their potential contribution as 'programmes of measures' under RBM. However, actions to implement these measures, for example ICWs predominantly in rural areas and broader implementation of green infrastructure in urban settings, does require action and investment by other parties which may not be aware of, or which may feel constrained by, the aspirations of a plan that they have not developed. Furthermore, Everard et al. (2012) highlight how narrow institutional perceptions tend still to thwart practical implementation of ICWs and other systemic solutions in practice, despite widespread recognition of their greater societal benefit. The advantage of interpreting integrated catchment management on the basis of the ecosystem approach is therefore that it provides a common language by which different sectors of society can plan for their own self-beneficial outcomes (for example less capital- and maintenance-intensive urban drainage solutions or treatment of farmyard run-off) while also collaborating and potentially pooling funding with co-beneficiaries (such as parks authorities, health interests, and fishery and catchment management agencies), all of which contributes to wider beneficial outcomes at catchment scale. IWRM and other integrated water and land management approaches thus become contextual settings to encourage others to innovate and contribute, respecting their focal goals and sovereignty, rather than being perceived as requirements to comply. The principles of the ecosystem approach also provide more detail than those outlined for IWRM, supporting interpretation of IWRM principles and their contribution to wider sustainable development goals in practice.

\section{Overcoming barriers}

The broadening of focus to address multiple service outcomes across whole systems requires interventions addressing the natural processes that produce multiple yet often formerly undervalued ecosystem services. However, this aspiration requires a shift in a number of landscapes.

Notwithstanding commitments to more systemic practice, the vast bulk of legacy regulation pertaining to the water cycle remains 'siloed', focusing for example on narrow flood risk, water quality or ecological end-points which, in isolation, create the potential for inadvertent negative consequences for other services over- 


\section{Offprint provided courtesy of www.icevirtuallibrary.com Author copy for personal use, not for distribution}

looked in the planning process. Examples addressed already in this paper include the climate-active, chemical-consuming and waste-generating impacts of advanced wastewater treatment put in place to improve the quality of receiving water bodies. Historic, narrowly framed approaches to flood defence and intensive farming have also eroded a range of non-target ecosystem services and their associated net societal value. Obviously, a renewed systemic approach is required in the policy environment.

'Ring-fenced' budgets reinforce the established fragmentation of policy and practice, and their associated potential for unintended negative consequences. Limitations on the target outcomes qualifying for investment of flood management levies favour traditional hard engineering 'flood defence' solutions, failing adequately to recognise the wider cumulative benefits arising from multiple services produced by natural process-based solutions such as wetland restoration, washlands, SuDS or managed realignment. A shift is therefore also necessary from costeffectiveness in delivery of narrowly framed outputs, towards calculating net benefit-to-cost reflecting a broad spectrum of ecosystem service outcomes.

Payments for ecosystem services (PES) schemes offer an emerging means to internalise formerly neglected ecosystem services into the economy through voluntary market agreements. PES schemes, rapidly advancing globally, operate by developing voluntary markets in which the beneficiaries of ecosystem services (many of whom may not currently perceive themselves as 'customers' of services formally assumed as 'free') pay 'producers' whose actions influence the maintenance and enhancement of the service of interest (Wunder, 2005). Upstream Thinking is an example of a PES scheme operated by a regional water utility (South West Water) on behalf of its customers, paying farmers via a trusted intermediary NGO (the Westcountry Rivers Trust) for land and farm management practices that better protect the quality of the resource of raw water, in turn making savings in treatment costs and water service customer bills. The OECD (2010) estimated that there were 300+ PES or 'PES-like' schemes operating globally. The uptake of PES schemes around the world has since accelerated, with the UK Government actively promoting PES through commitments in its Natural Environment White Paper (HM Government, 2011) including a PES Best Practice Guide (Smith et al., 2013). This demonstrates that economic tools are also developing to overcome historic barriers presented by the current market.

The assumptions of many practitioners are heavily shaped by precedents and established practices, including solutions offered by consultancies with sunk investments in engineering approaches and models which will also need to evolve to take account of systemic outcomes. Selection and further innovation of novel, multi-benefit technical solutions will be essential to deliver this major shift in culture in practical terms, as well as in the vision and mandate of institutions established to manage catchments and other ecosystems. Professional associations may offer a coordinated means to reach out to inform and promote innovation among these influential networks.

\section{Discussion}

Europe's industrial past, reflected today in the legacy of the market economy, regulation and business assumptions, is founded on a conception of the natural world as an inherently boundless resource available for conversion into products and profit (Hawken, 1993). Profit, in turn, has generally been taken as a surrogate for human development, regardless of the longer-term degradation by profit-generating activities of the ecosystem resources essential for continuing human wellbeing (Millennium Ecosystem Assessment, 2005). This inherently exploitative and unsustainable economic model can operate only while there are sufficient unexploited ecosystem resources to access, and as often to liquidate. The quest for fresh sources of natural resources explains much of the history of empire-building by European nations benefiting from the first wave of industrialisation from the mid-eighteenth century. Awareness of natural limits has evolved from Thomas Malthus (1798) and the Club of Rome's Limits to Growth (Meadows et al., 1972), and is now most dramatically demonstrated as a daunting challenge for future human wellbeing by the Millennium Ecosystem Assessment (2005) and the UK National Ecosystem Assessment (2011). These studies demonstrate the necessity of safeguarding ecosystems and natural processes as fundamental resources underpinning the needs and demands of a burgeoning global human population.

The ecosystem services framework and the contextual setting of the ecosystem approach provide an integrated means to consider the broader implications for human wellbeing of policies and management options. Bringing all services together into an interconnected framework enables better engagement and participation of the disparate beneficiaries of natural processes, a central but often overlooked principal of the ecosystem approach, to generate more robust, publicly beneficial and readily accepted development options and improved recognition and resolution of potential trade-offs. By so doing, the ecosystem services framework provides a spur to innovation of 'systemic solutions' to maximise public value through optimisation of beneficial outcomes.

A systemic approach addressing all aspects of human wellbeing simultaneously is also more economically efficient (Millennium Ecosystem Assessment, 2005) by helping avert 'negative externalities' (unintended costs), enhancing public value through optimising multiple service production per unit of investment, and communicating the implications of policies and management or development options more intuitively to a greater diversity of stakeholders, which also reduces the transaction costs of decision making. Value can also be created by 'natural solutions', such as green infrastructure, which may enhance the value of real estate in proximity to green spaces, rivers and other natural features 


\section{Offprint provided courtesy of www.icevirtuallibrary.com Author copy for personal use, not for distribution}

(Millennium Ecosystem Assessment, 2005). More sustainable 'systemic solutions' that work with, rather than in opposition to, natural processes also tend to be more durable, yielding greater public value and reducing lifetime management inputs.

The explicit inclusion of people in the decision-making process is also a key principle of the ecosystem approach, ensuring that the voices and different forms of knowledge of all affected people are heard and included alongside 'expert' knowledge in decisionmaking processes. This requires a review of decision-support tools. For example, at least in Europe and the USA, technical, top-down assumptions and solutions have typically been embedded in modelling. Modelling has and will continue to play an important role in environmental management, but needs to become more permeable and interactive to engage with rather than exclude the diversity of beneficiaries of the many services provided by ecosystems.

Evidence about the need for a transition from the historic focus on technical solutions to narrowly framed problems towards more flexible, inclusive and outcome-focused multi-benefit solutions is compelling. More sustainable, multiple-outcome solutions are a necessity in a climate-changing, resource-limited world with spiralling demands due to increasing global population and middle-class lifestyles. There is also a compelling economic case for achieving more beneficial outcomes per unit of investment and resource use by optimising the production of ecosystem services through reform of policy, financial accounting, modelling approaches, professional advice and participatory practice. This includes challenging fixed assumptions that decision makers may hold about solutions to problems, and the freedom to innovate and challenge established practice, as highlighted by factors holding back more widespread uptake of ICWs, including narrow regulatory thinking, differences in views about the value of land between regulated farmers and regulatory decision makers, and risk aversion (Everard et al., 2012).

Systemic changes in culture are necessarily slow, requiring not merely technical and economic but also 'hearts and minds' demonstration of the benefits of undertaking a more sustainable approach. However, none of the barriers identified is insurmountable, as demonstrated by the progressive innovation and (albeit currently slow) uptake of 'systemic solutions' such as evolving approaches to SuDS, GI, ICWs, river restoration, catchmentbased water industry investment and expanding PES approaches. All are evolving in the scope of connected outcomes that they address, and in the extent of uptake into routine practice. All also highlight 'systemic solutions' principles - low input solutions working with natural processes yet seeking to optimise outcomes across the spectrum of ecosystem services - that may be beneficially deployed in other environmental and resource management situations.

The ecosystem approach is not without its perceived drawbacks, particularly with respect to the fact that it represents a broader world view that challenges the orthodoxy of siloed regulation, budgets, institutional responsibilities, investment by technical solutions providers and other vested interest in the status quo. Indeed, as discussed, many of these factors remain considerable constraints to progress towards more sustainable, multi-beneficial outcomes, such that nearly 20 years since the ecosystem approach was proposed there is still plenty of scope to realise it in practice. Another difficulty is of course widespread understanding of all of the principles of the ecosystem approach, as well as innovation of social processes to deliberate on a representative but also a cost-efficient way. Undoubtedly, further innovation is required to bring these practices more commonly into the mainstream.

However, the benefits of systemic management are becoming better understood and demonstrated. Their progressive 'mainstreaming' will rely not merely on adaptation of policy, economic and stakeholder engagement processes, but also the ingenuity of engineers to innovate genuinely systemic, multi-benefit solutions optimising public value by addressing the full suite of beneficial ecosystem services. Engineers and their professional networks and institutions therefore have a key influential role to play in changing thinking processes, and developing plausible solutions and novel technologies to achieve more multi-benefit, costeffective and sustainable outcomes, encouraging societal transition towards a sustainable relationship with the water cycle and other life support systems.

\section{REFERENCES}

Allan T (2003) IWRM/IWRAM: a new sanctioned discourse. Occasional Paper 50. SOAS Water Issues Study Group, School of Oriental and African Studies/King's College London, University of London, London, UK.

Born SM and Sonzogni WC (1995) Integrated environmental management: strengthening the conceptualization. Environmental Management 19(2): 167-181.

Calder IR (1999) The Blue Revolution: Land Use and Integrated Water Resources Management. Earthscan Publications, London, UK.

Center for Clean Air Policy (2011) The Value of Green Infrastructure for Urban Climate Adaptation. Center for Clean Air Policy, Washington DC, USA.

Crutzen PJ and Stoermer EF (2000) The 'Anthropocene'. Global Change Newsletter 41: 17-18.

Defra (Department for Environment, Food and Rural Affairs) (2005) Making Space for Water: Taking Forward a New Government Strategy for Flood and Coastal Erosion Risk Management in England. First Government response to the autumn 2004 'Making space for water' consultation exercise, March 2005. Defra, London, UK.

Defra (2013) Catchment Based Approach: Improving the Quality of our Water Environment. Defra, London, UK. See http:// www.gov.uk/government/publications/catchment-basedapproach-improving-the-quality-of-our-water-environment (accessed 20/11/2013). 
Dunse N, Dehring C and White M (2007) Urban Parks, Open Space and Residential Property Values. FiBRE (Findings in Built and Rural Environments), Royal Institute of Chartered Surveyors, London, UK

Everard M (2011) Why does 'good ecological status' matter. Water and Environment Journal 26(2): 165-174.

Everard M (2012) What have rivers ever done for us? Ecosystem services and river systems. In River Conservation and Management (Boon PJ and Raven PJ (eds)). Wiley, Chichester, UK, pp. 313-324.

Everard M and McInnes RJ (2013) Systemic solutions for multibenefit water and environmental management. The Science of the Total Environment 461(62): 170-179.

Everard M and Moggridge HL (2012) Rediscovering the value of urban rivers. Urban Ecosystems 15(2): 293-314.

Everard M, Shuker L and Gurnell AM (2011) The Mayes Brook Restoration in Mayesbrook Park, East London: the Additional Benefits of River Restoration. Environment Agency, Bristol, UK. Environment Agency Evidence Report. See cdn.environment-agency.gov.uk/scho0610bsow-e-e.pdf (accessed 04/03/2014).

Everard M, Harrington R and Mclnnes RJ (2012) Facilitating implementation of landscape-scale integrated water management: the integrated constructed wetland concept. Ecosystem Services 2: 27-37.

European Commission (2000) Directive 2000/60/EC of the European Parliament and of the Council establishing a framework for the Community action in the field of water policy. See http://ec.europa.eu/environment/water/waterframework/index_en.html (accessed 04/03/2014).

Grant G (2012) Ecosystem Services Come to Town: Greening Cities by Working with Nature. Wiley-Blackwell, Chichester, UK.

Global Water Partnership (2000) Integrated Water Resources Management. Global Water Partnership, Stockholm, Sweden, GWP Technical Committee Background Paper 4

Hardin G (1968) The tragedy of the commons. Science 162: $1243-1248$

Hawken P (1993) The Ecology of Commerce: A Declaration of Sustainability. HarperCollins, New York, USA.

HM Government (2011) The Natural Choice: Securing the Value of Nature. The Stationary Office, London, UK.

Malthus T (1798) An Essay on the Principle of Population. Penguin Classics, London, UK. Available in many subsequent impressions including reproduction of the 1798,1 st edition with A Summary View (1830), and Introduction by Professor Antony Flew.

Meadows DH, Meadows DL, Randers J and Behrens III WW (1972) The Limits to Growth. Universe Books, New York, USA.

Meijerinka S and Dicke W (2008) Shifts in the public-private divide in flood management. International Journal of Water Resources Development 24(4): 499-512.

Millennium Ecosystem Assessment (2005) Ecosystems and Human Well-being. Island Press, Washington, DC, USA.
Mitchell B (2004) Discussion note: comments by Bruce Mitchell on water forum contribution 'Integrated water resources management: a reassessment' by Asit K Biswas. Water International 29: 398-405.

Mitchell B and Hollick M (1993) Integrated catchment management in Western Australia: transition from concept to implementation. Environmental Management 17: $735-743$

Natural England (2009) Green Infrastructure Guidance (NE176). Natural England, Peterborough, UK. See http:// publications.naturalengland.org.uk/publication/35033 (accessed 20/11/2013).

OECD (2010) Paying for Biodiversity: Enhancing the CostEffectiveness of Payments for Ecosystem Services. OECD Publishing, Paris, France. See http://dx.doi.org/10.1787/ 9789264090279-en (accessed 04/03/2014).

Pahl-Wostl C and Sendzimir J (2005) The Relationship between IWRM and Adaptive Management. NeWater Report Series No. 3. NeWater project. See www.newater.info (accessed 04/03/2014)

Pitt M (2007) The Pitt Review: Lessons learned from the 2007 Floods. Cabinet Office, London. See http:// webarchive.nationalarchives.gov.uk/20080906001345/ cabinetoffice.gov.uk/thepittreview.aspx (accessed 20/11/2013).

Radif AA (1999) Integrated water resources management (IWRM): an approach to face the challenges of the next century and to avert future crises. Desalinsation 124: 145-153.

Republic of South Africa (1912) Irrigation and Conservation of Waters Act 1912 (Act 8 of 1912). Republic of South Africa.

Saravanan VS, McDonald GT and Mollinga PP (2009) Critical review of integrated water resources management: moving beyond polarised discourse. Natural Resources Forum 33: $76-86$

Scholz M, Harrington R, Carroll P and Mustafa A (2007) The integrated constructed wetlands (ICW) concept. Wetlands 27: $337-354$

Smith S, Rowcroft P, Everard M et al. (2013) Payments for Ecosystem Services: A Best Practice Guide. Department for Environment, Food and Rural Affairs, London, UK.

South West Water (2012) Corporate Sustainability Report 2012. South West Water, Exeter, UK. See http://www.sww-crreport-2012.com/environmental-sustainability/upstreamthinking/ (accessed 09/02/2014).

Trust for Public Land (2008) How Much Value does the City of Philadelphia Receive from its Park and Recreation System. See cloud.tpl.org/pubs/ccpe_PhilaParkValueReport.pdf (accessed 20/11/2013).

UK National Ecosystem Assessment (2011) The UK National Ecosystem Assessment: Synthesis of the Key Findings. UNEPWCMC, Cambridge, UK. See http://uknea.unep-wcmc.org/ (accessed 20/11/2013).

Urban Parks Forum (2002) Your Parks: The Benefits of Parks and Greenspace. Urban Parks Forum, see http://www. urbanparksforum.co.uk/ (accessed 04/03/2014).

Woods-Ballard B, Kellagher R, Martin P et al. (2007) The SUDS 
Manual. Construction Industry Research and Information Association, London, UK, CIRIA Report C697.

World Health Organization (2005) Ecosystems and Human Wellbeing: Health Synthesis - A Report of the Millennium

Ecosystem Assessment. World Health Organization, Geneva,
Switzerland. See www.who.int/globalchange/ecosystems/ ecosystems05/ (accessed 20/11/2013).

Wunder S (2005) Payments for Environmental Services: Some Nuts and Bolts. Center for International Forestry Research, Bogor, Indonesia, CIFOR Occasional Paper No. 42.

\section{WHAT DO YOU THINK?}

To discuss this paper, please email up to 500 words to the editor at journals@ice.org.uk. Your contribution will be forwarded to the author(s) for a reply and, if considered appropriate by the editorial panel, will be published as a discussion in a future issue of the journal.

Proceedings journals rely entirely on contributions sent in by civil engineering professionals, academics and students. Papers should be 2000-5000 words long (briefing papers should be 1000-2000 words long), with adequate illustrations and references. You can submit your paper online via www.icevirtuallibrary.com/content/journals, where you will also find detailed author guidelines. 